\title{
Induced Pluripotent Stem Cells (iPSCs) in Vascular Research: from Two- to Three-Dimensional Organoids
}

\author{
Anja Trillhaase ${ }^{1,2,3} \cdot$ Marlon Maertens ${ }^{1,2,3} \cdot$ Zouhair Aherrahrou $^{1,2,3} \cdot$ Jeanette Erdmann ${ }^{1,2,3}$ (D)
}

Accepted: 4 March 2021 / Published online: 18 March 2021

(C) The Author(s) 2021

\begin{abstract}
Stem cell technology has been around for almost 30 years and in that time has grown into an enormous field. The stem cell technique progressed from the first successful isolation of mammalian embryonic stem cells (ESCs) in the 1990s, to the production of human induced-pluripotent stem cells (iPSCs) in the early 2000s, to finally culminate in the differentiation of pluripotent cells into highly specialized cell types, such as neurons, endothelial cells (ECs), cardiomyocytes, fibroblasts, and lung and intestinal cells, in the last decades. In recent times, we have attained a new height in stem cell research whereby we can produce $3 \mathrm{D}$ organoids derived from stem cells that more accurately mimic the in vivo environment. This review summarizes the development of stem cell research in the context of vascular research ranging from differentiation techniques of ECs and smooth muscle cells (SMCs) to the generation of vascularized 3D organoids. Furthermore, the different techniques are critically reviewed, and future applications of current 3D models are reported.
\end{abstract}

Keywords Induced pluripotent stem cells $\cdot$ Differentiation $\cdot$ Smooth muscle cells $\cdot$ Endothelial cells $\cdot$ Organoids $\cdot$ Vasculature

\section{Development and Progress of Human iPSC Technology over the Last Years}

Human induced-pluripotent stem cells (iPSCs) are a recent alternative to embryonic stem cells (ESCs) that can be generated from adult somatic tissue without the need of embryos. The technique was developed in the early 2000s when Thomson and colleagues successfully isolated human ESCs from preimplantation embryos in 1998 (Thomson, 1998). To generate iPSCs, adult somatic cells were reprogrammed by forced expression of pluripotency factors, four of which were discovered by Yamanaka and Takahashi in 2006. Takahashi and colleagues were able to reprogram mouse fibroblasts with the overexpression of Octamer-binding transcription factor 4 (OCT4), sex determining region Y-box 2 (SOX2), Kruppel-

Anja Trillhaase and Marlon Maertens contributed equally to this work.

Jeanette Erdmann

jeanette.erdmann@uni-luebeck.de

1 Institute for Cardiogenetics, University of Luebeck, Ratzeburger Allee 160, 23562 Luebeck, Germany

2 DZHK (German Centre for Cardiovascular Research), Partner Site Hamburg/Kiel/Luebeck, Luebeck, Germany

3 University Heart Centre Luebeck, 23562 Luebeck, Germany like factor 4 (KLF4), and v-Myc avian myelocytomatosis viral oncogene homolog (Myc, alias $c-M Y C$ ), delivered with the help of a retrovirus [1]. In 2012, John B. Gurdon and Shinya Yamanaka were awarded the Nobel prize for Physiology or Medicine "for the discovery that mature cells can be reprogrammed to become pluripotent" (Press release. NobelPrize.org. Nobel Media AB 2020. Mon. 27 Apr 2020). Importantly, iPSCs can be generated from numerous somatic cell types, including a small skin biopsy, without putting the patient at risk of undergoing invasive surgery [2]. Nowadays, various iPSC-derived models exist to examine disease pathology and the influence of genetic risk factors on disease progression. Cell types, such as neurons, smooth muscle cells (SMCs), cardiomyocytes, and fibroblasts, as well as endothelial, lung, and intestinal cells, can be differentiated from iPSCs. However, there are only a few models for vascular cell derivatives (Fig. 1).

Previously, two-dimensional (2D) differentiation methods were the state-of-the-art technology, allowing researchers to closely monitor and manipulate single cells during maintenance and differentiation. 2D systems are efficient, simpleto-handle, and cheap [3]. However, 2D cell culture models do not reflect the natural microenvironment or physiology, including cell-cell interactions [4]. Additionally, 2D cultured cells differ in morphology and behaviour from their counterparts in vivo [4]. Therefore, three-dimensional (3D) culture 


\section{Achievements and Milestones in iPSC research}

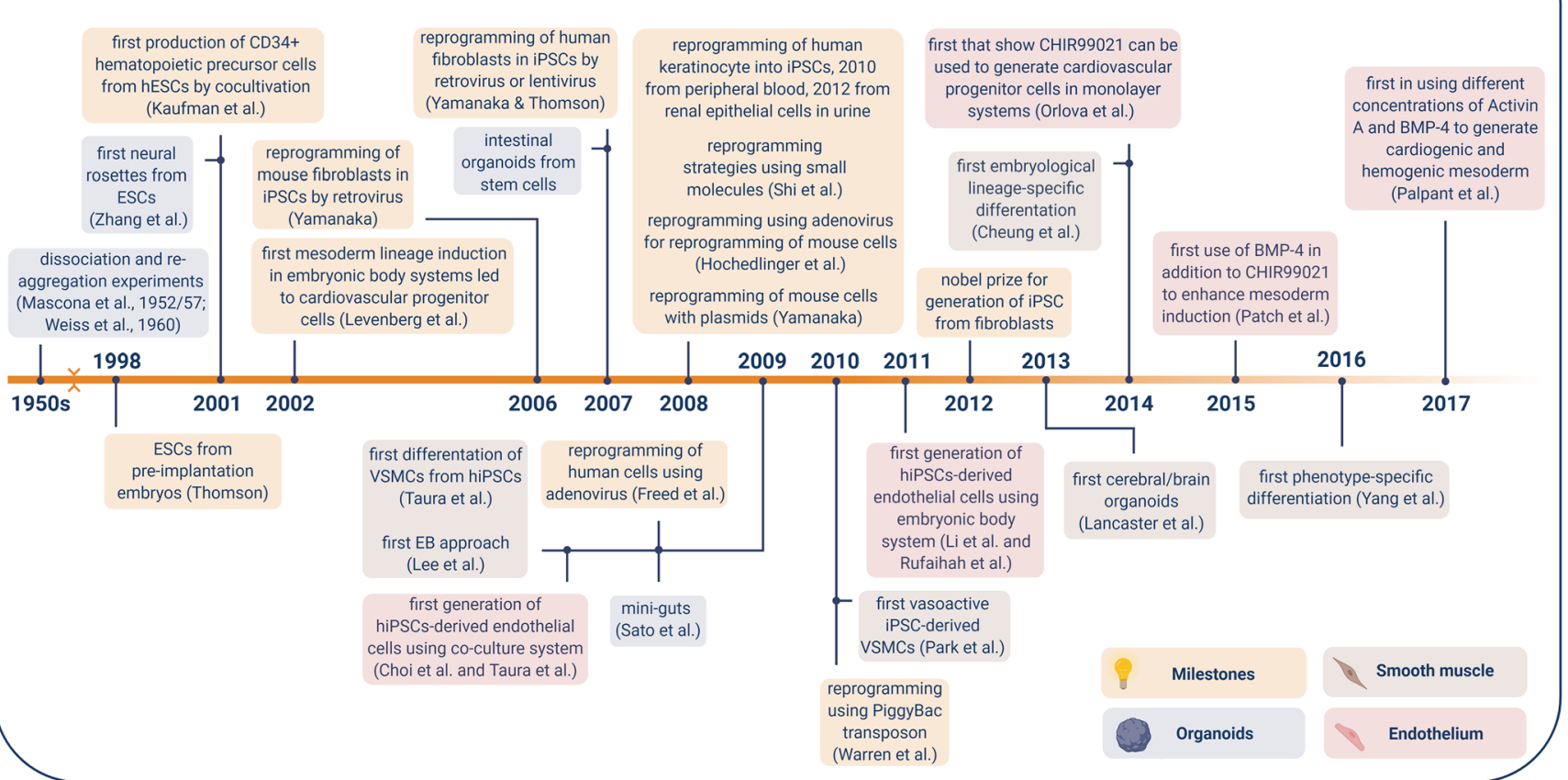

Fig. 1 Achievements and Milestones in iPSC research. Timeline showing the achievements of iPSC technology since 1998, divided into general milestones and time-points when smooth muscle and endothelial cell derivatives were successful generated

systems were warranted to accurately mimic the in vivo environment.

Recently, 3D organoids and tissue models have been generated from iPSCs to resemble organ structure and function. Examples of complex tissues and organs modelled in 3D include Engineered Heart Tissues (EHTs) [5], Lung [6], and intestinal organoids [7], as well as so-called "mini-brains" [8]. A 3D model of the vascular system was only recently published [9].

Independent of format, one of the main questions evaluated during the emergence of differentiation methods of pluripotent stem cells (PSCs) was whether directed or undirected differentiation approaches were more feasible. For some time, it was the standard to use embryoid bodies for differentiation of specific tissues. However, this method has some disadvantages such as the lack of control over the different cell types that reside in the differentiated cell culture. It is not possible to control and regulate the differentiation path of every single cell. Cells spontaneously start differentiating, then spontaneously transmit signals to surrounding cells randomly initiating other differentiation and signalling cascades without the possibility to control the direction [10]. On the other hand, many developmental studies revealed very detailed signalling cascades leading to specific, lineage-imbedded mature cells. This method usually progresses via precursor cells of the respective tissue type and is now used in many differentiation protocols. The differentiation factors used are usually well defined and allow a cell type specific differentiation, in some cases even a differentiation of subtypes of cells [10]. In terms of organoid differentiation also two methods are known today. Organoids exclusively differentiated from PSCs often result in a heterogeneous and immature cell population. Organoids however, that were differentiated from lineage-specific precursors often mimic the physicochemical characteristics of the niche better and therefore are able to induce maturation. Further, using precursors for organoid formation makes it easier to keep control over the cells and their development within the organoid, as they are already induced into a specific lineage before formation of the organoid.

\section{Vessel Structure and Cell Types}

The cardiovascular system is one of our largest organs, consisting of arteries, veins, and capillaries. Cardiovascular disease (CVD) occurs primarily in arteries that transport oxygenated blood from the heart to different regions of our body. The heart artery walls consist of three different layers that surround a central lumen. Each of these layers are composed of different cells and extracellular matrix molecules. As a result, each layer may function differently in terms of homeostatic regulation and growth. The innermost layer, tunica inti$\mathrm{ma}$, is in direct contact with the blood. It consists of a monolayer of endothelial cells (ECs), connective tissue, and resident smooth muscle cells (SMCs). The internal elastic membrane forms a barrier with the thick middle layer, the tunica media, 
consisting of SMCs and elastic fibres. The outermost layer is the tunica adventitia, consisting of an elastic membrane, connective tissue, fibroblasts, SMCs, mast cells, as well as nervi and vasa vasorum (Fig. 2) [11-14]. Thus, reconstruction and engineering of the vessel in vitro is challenging. Indeed, we are just beginning to understand the cell-cell interactions, especially between resident ECs and SMCs. Nowadays, SMCs and ECs can be easily differentiated from iPSCs and produced at a large scale.

\section{iPSC-Derived Endothelial Cells}

The ECs form the innermost layer of our vessels and are responsible for the direct contact between blood and tissue. The ECs have a combined surface area of approximately 10 basketball courts [15]. Besides their role in vaso-dilatory and constrictive processes, they are also responsible for homeostatic and signal transducing processes. Therefore, the vascular endothelium is of particular interest, especially regarding the development and progression of vascular diseases, such as myocardial infarction, stroke, neurovascular disorders, and atherosclerosis [16-18].

At the beginning of this century, scientists were reliant on the use of primary or hESC-derived ECs for vascular research. Since the discovery of iPSCs, it has been possible to produce patient-derived ECs to investigate the development and progression of cardiovascular diseases, or the individual effects of different drugs. In addition, iPSCs also offer other advantages, such as the ethical renunciation of hESCs, the avoidance of immune reactions upon implantation, the generation of geneedited cells with isogenic background, and the scalable production of cellular materials for research $[9,19,20]$. Recently, organoids have aided the investigation of diseases, which can be achieved with a homogeneous and well-defined iPSC-derived EC line [21].

The monolayer differentiation method is most widely used in stem cell research. To understand how this method came into use, one should take a brief look into the achievements of the last 20 years. In 2001, Kaufman et al. succeeded in producing CD34 positive (+) hematopoietic precursor cells from hESCs by co-cultivation with mouse bone marrow stromal cell lines [22]. Later, it was discovered that mesoderm lineage induction by the embryoid body (EB) method led to cardiovascular progenitor cells from which ECs could be produced [23-25]. Then, in 2009, Choi et al. and Taura et al. demonstrated that ECs could be derived from hiPSCs [26, 27]. Until now, different techniques have been reported to improve the efficiency and quality of iPSC-derived ECs, in terms of characteristic markers and function. In the following review, we will highlight and discuss the various differentiation techniques that have been in use for approximately 10 years, including their advantages and disadvantages (Table 1).

\section{Co-culture Systems}

In 2009, Choi et al. and Taura et al. were the first to successfully generate ECs from hiPSCs. They showed very similar

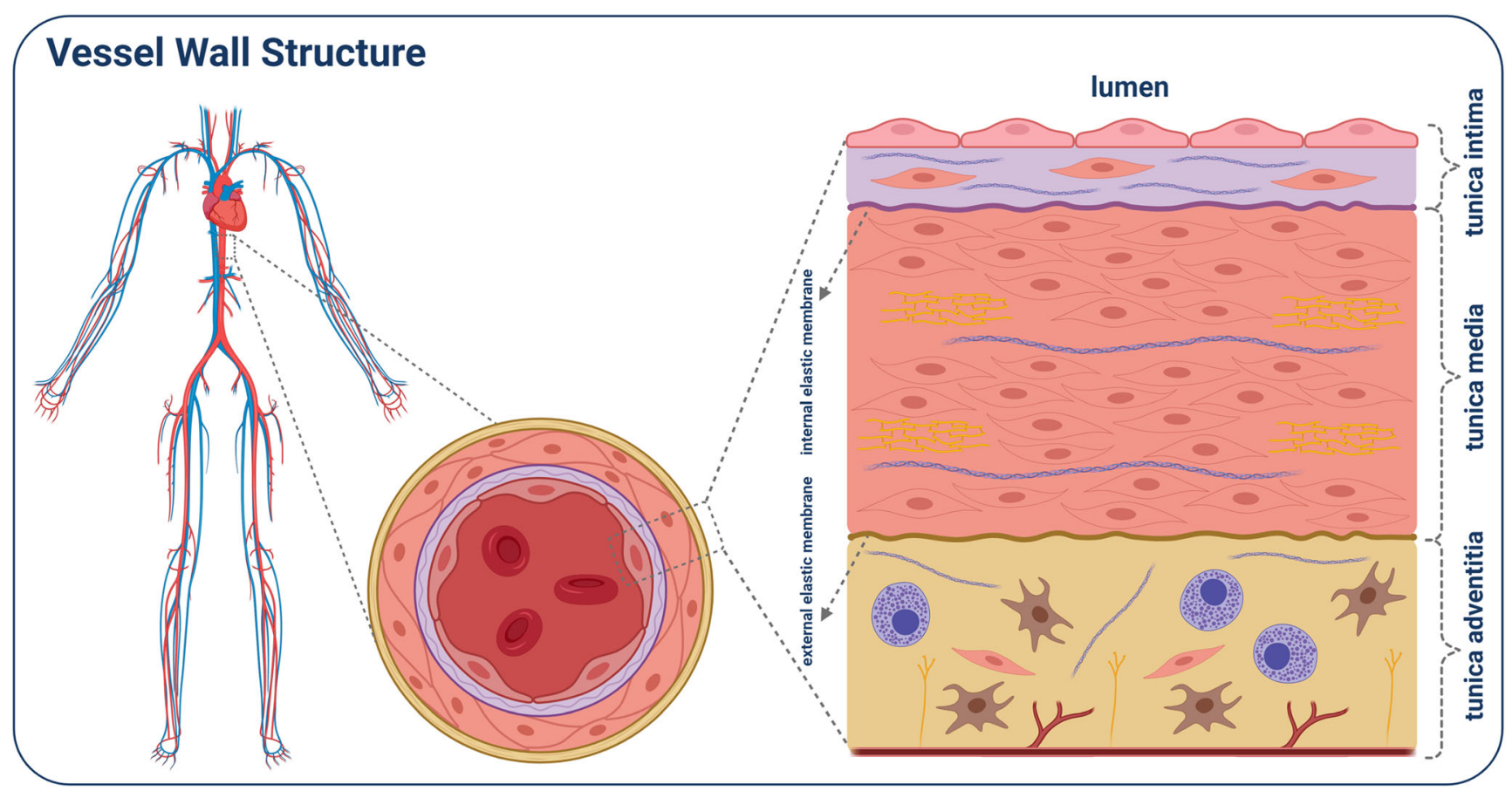

Fig. 2 Shown is the human vascular system, with a magnified transverse section through the aorta. Further magnified is a cross-section of the vessel wall, divided into the different layers with the corresponding components 
properties regarding marker expression, tube formation, and cell behaviour. Both groups used co-culture techniques, in which stem cells (SCs) were cultivated together with mouse bone marrow stromal cell lines, such as OP9 or S17, for 8 to 10 days. Feeder cells provided the SCs with an environment for spontaneous differentiation into CD34+ hematoendothelial precursors cells (HEPs). By using magnet-activated cell sorting (MACS) CD34+ cells were specifically isolated. Subsequently, the sorted cells could be differentiated in the direction of the EC lineage by culturing in EC medium supplemented with basic fibroblast growth factor (bFGF) and vascular endothelial growth factor (VEGF). The groups showed that these cells expressed characteristic EC markers such as CD144, vWF, CD309, CD31, CD49d, and CD105, but the total differentiation efficiency was very low $[26,27]$. The co-culture systems used to derive hematopoietic lineages from iPSCs have considerable disadvantages. In addition to their low EC differentiation efficiency, these cultures required the support of animal feeder cells. Due to immunogenicity, this would make implantation into patients practically impossible. Moreover, the co-culture method sometimes required long differentiation times and led to high cell heterogeneity. The latter leads to a mixture of different cell subpopulations, which accordingly, may bias the study results.

\section{Embryoid Body Systems}

The use of EBs to obtain ECs from ESCs has been extensively researched [24, 25]. In 2011, Li et al. and Rufaihah et al. used the EB technique to generate hiPSC-derived ECs [28, 29]. Briefly, iPSC colonies are cultivated in ultra-low binding tubes for several days to form cell aggregates. In this state, internal cells not exposed to the external environment are triggered to undergo spontaneous differentiation. After 4 to 12 days of spontaneous differentiation, the EBs were transferred into adherent conditions supplemented with VEGF and bFGF for another 3 to 10 days to form ECs [28, 29].

Later, this method was refined by culturing the EBs for 4 days with bone morphogenetic protein 4 (BMP-4) and VEGF-A, followed by differentiation into EC subtypes with slight culturing modifications. For a heterogeneous population of ECs, 4-day-old EBs were re-attached and cultured with VEGF-A alone. For arterial EC differentiation, the EBs were cultured with the addition of 8-Bromoadenosine cyclic adenosine monophosphate (8Br-cAMP). For venous EC differentiation, EBs were cultured with VEGF-A alone. For lymphatic EC differentiation, EBs were cultured with BMP-4, VEGF-C, and angiopoietin-1 [30].

In $2012 \mathrm{Xu}$ and colleagues published an EC differentiation method using a chemically defined cocktail [31]. They used stem cell factor (SCF), FMS-like tyrosine kinase 3 ligand (FLT3L), and VEGF during EB formation for mesoderm induction. CD34+ induction was achieved with the addition of
bFGF, IL-3, IL-6, VEGF, FLT3L, and SCF. After EB dissociation and sorting, the CD34+ cells were cultured with VEGF-A to initiate differentiation into ECs. This approach was not efficient, yielding 13\% CD34+ cells, and not costefficient due to the number of factors required [31].

To generate a pure culture of ECs with the same functional phenotypic plasticity of mature primary vascular endothelium, Adams et al. dissociated the EBs, sorted, and subsequently cultivated the CD144+ cells in EC medium [32]. The sorting step was necessary because CD31+ and CD309+ cells do not express CD144. This result is problematic for previous studies because CD144 is a highly specific marker of EC identity. It is important to note that the EB differentiation efficiency from CD144+/CD31+ cells was $18 \%$ [32].

Just like co-culture systems, the EB method has many disadvantages. The EB method yields to a highly heterogeneous cell population with low EC efficiency. Based on these reasons, the EB method is unfavourable for high-throughput models, which need a large number of homogenous cells.

\section{Monolayer Systems}

Park et al. 2010 were among the first to develop a monolayer system that did not require additional feeder cells. Instead, the authors demonstrated that mesoderm induction from PSCs is a key step towards generating hematoendothelial precursor cells [33]. Commitment into the mesoderm lineage did not require the formation of EBs, or co-culture with mouse bone marrow stromal cell lines; instead, it could be induced by BMP-4 alone. Additionally, PD98059 (a potent and selective inhibitor of MAPkinase kinases) was shown to increase mesoderm induction. Furthermore, they found that BMP-4 did not prevent further differentiation of $\mathrm{CD} 34+$ cells. However, the overall differentiation efficiency of CD34+ cells was only $13 \%$. For differentiation of ECs, treatment with bFGF and VEGF-A was sufficient [33].

In the same year, Homma and colleagues published an undirect differentiation method in which iPSCs were incubated with N2 and B27 supplement for three days [34]. After another three to five days with StemPro-34 SFM and VEGF, the CD309+ and CD144+ cells were sorted and used for functional analysis. Experimentally, the authors were able to show that iPSC-derived ECs have a greater wound healing capacity and oxidative stress tolerance than human aortic endothelial cells (HAECs). Moreover such ECs have a comparable localization of eNOS, CD31 and CD144 in immunofluorescence analysis compared with HAECs [34].

Orlova and colleagues 2014 showed that CHIR99021 (an inhibitor of the enzyme GSK-3) was sufficient to start mesoderm induction in monolayer culture, while Patsch et al. 2015 reported that the addition of BMP-4 increased the yield [35, 36]. Further, Patsch et al. 2015 presented an optimised differentiation method for generating ECs. First, the researchers 
treated hiPSCs with BMP-4 and CHIR99021 up to day 4 to generate mesodermal cells, followed by a cocktail consisting of Forskolin and VEGF-A to induce ECs up to day 6. For the maturation of the ECs, the researchers continued treatment with VEGF-A. This protocol circumvented the use of feeder cells or EBs, and was shorter, more cost-effective, and yielded 30 times more ECs from iPSC-derived mesodermal SC precursors. From 1 million iPSCs, 30 million ECs can be produced. An additional advantage of this protocol is that the EC cocktail can be modified to an SMC cocktail after mesoderm induction to produce SMCs instead of ECs. This modification consists in the use of N2B27 medium plus PDGF-BB and Activin A from day 4 for SMC induction and from day 6 additionally heparin for maturation into VSMCs $[35,36]$.

Two years later, Ikuno et al. published an enhanced differentiation protocol that could yield 10 times more ECs than the Patsch method [37]. This was achieved by the addition of cAMP as an inducer for early mesoderm and early EC commitment. This was based on the activation of protein kinase $\mathrm{A}$ (PKA) by cAMP, which resulted in increased expression of VEGFR2 and PKA-activated CREB-mediated activation of Etv2/ER71 (an ETS transcription factor) for early EC commitment. Another interesting aspect of the Ikuno et al. study is the so-called stimulation-elimination method. After mesoderm induction, a stimulation step is performed for 2 days by treatment with VEGF and cAMP, and then all non-responder cells are eliminated by VEGFR2+ Fluorescence-activated cell sorting (FACS). The responder cells were then stimulated for another 3 days. By eliminating the non-responder cells early, the resulting population was $99 \%$ pure ECs. This stimulation-elimination method eliminates the need to purify the cells at a mature cell stage, which in turn increases the yield and viability of ECs [37].

In the same year, Palpant and colleagues demonstrated the importance of cellular polarization for differentiation of mesoderm subtypes [38]. They used different concentrations of Activin A and BMP-4 to generate cardiogenic and hemogenic mesoderm, respectively. From these subtypes, both cardiomyocytes and functionally diverse ECs could be differentiated (Fig. 3). This work clearly showed the importance of considering the endothelial lineages. Depending on the desired function or target site, the different lineages must be considered. Therefore, it is necessary to know in advance which endothelial subtype, whether endocardial, vascular (venous or arterial), or lymphatic, is required [30, 38, 39].

The large amount of publications and differentiation protocols reflects the interest in this developing field, with a new focus on $3 \mathrm{D}$ cultures of organoids and tissues. The optimised monolayer-based methods of EC generation will continue to be used in the field, based on reliability and high-yield differentiation, which could also be applied at an industrial scale. Nevertheless, further studies will be necessary to elucidate lineage specificity, so that it is possible to differentiate functionally distinct ECs that are tailored to their destination. Regarding therapeutic application, further knowledge is needed to reduce the use of immunogenic substances, such as fetal bovine serum (FBS), or animal-derived coating matrices.

\section{iPSC-Derived Vascular Smooth Muscle Cells}

Obtaining primary vascular SMCs from patients is difficult and highly invasive. A better alternative is to differentiate vascular SMCs (VSMCs) from patient-derived iPSCs. However, to date, only a few VSMC differentiation protocols have been reported (Table 1). In 2009, Xie and colleagues published a method using all-trans retinoic acid (RA) for the differentiation of murine SCs into VSMCs [40]. This method is also effective for human PSCs (Trillhaase, 2020). Importantly, treatment of iPSCs with RA for 10 days leads to spontaneous differentiation into VSMCs. Therefore, the resulting VSMC population will be a heterogeneous mix of SMCs from different embryonic origins. Nonetheless, these VSMCs express SMC-specific markers like alpha smooth muscle actin (SMA) and smooth muscle myosin heavy chain (MHC) [40].

During embryonic development, VSMCs originate from the neuroectoderm (NE), lateral-plate mesoderm (LM), and paraxial mesoderm (PM) lineages [41]. In 2014, Cheung and colleagues published a protocol that facilitated lineage specification for VSMC differentiation [41]. To specify the NE, human PSCs were treated with FGF2 and SB431542 for 7 days [41]. For LM and PM specification, the PSCs were first differentiated into early mesoderm by supplementation with FGF2, LY294002, and BMP-4 for 1.5 days, followed by either FGF2 and high LY294002 supplementation, or FGF2 and high BMP-4 supplementation, for PM and LM specification, respectively [41]. To differentiate SMCs, the specified cells were then treated with platelet-derived growth factor (PDGFBB) and transforming growth factor beta (TGFbeta1) [41]. This method closely mimicked embryonic development as reported by Sinha and colleagues [42] and can be used to investigate VSMCs from a specific lineage (Fig. 3).

The vascular system is made up of VSMCs derived from different lineages. Cells of the NE lineage give rise to VSMCs in the ascending aorta, the aortic arch, and the pulmonary trunk [43]. VSMCs from the PM are found in the descending aorta [42]. VSMCs from the LM are first located in the proepicardium in the looped-heart stage of embryogenesis and then settle at the venous pole [42].

In the vascular system, VSMCs are an important regulator of blood flow and pressure [43]. Due to their contractile ability, they are responsible for vaso-dilatation and constriction, and blood flow dispersion [44, 45]. An important characteristic of VSMCs is their ability to switch from a contractile to a synthetic phenotype. The synthetic phenotype is mediated by PDGF, bFGF, insulin-like growth factors, epidermal growth 


\section{From iPSCs to}

smooth muscle cells

\& endothelial cells

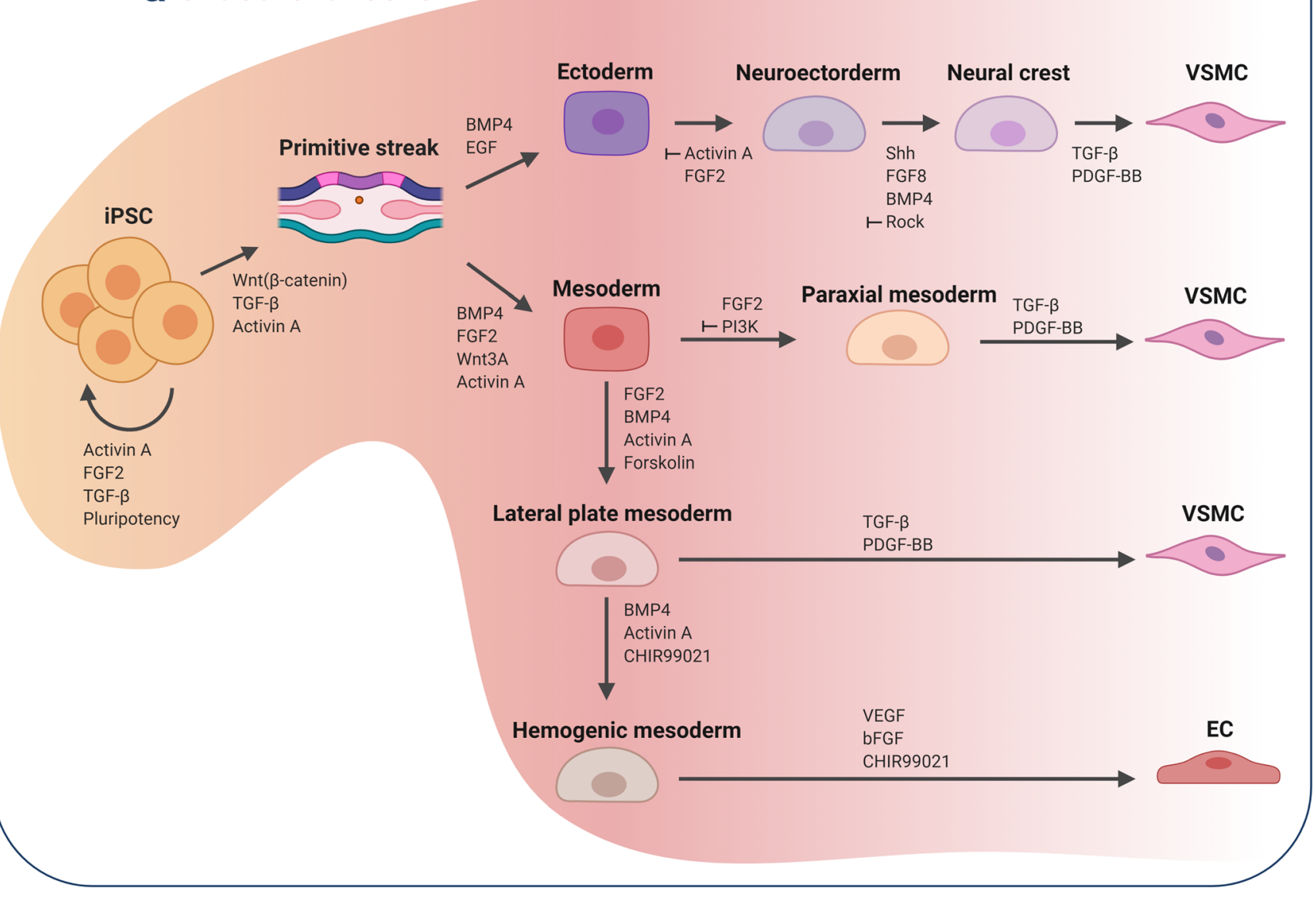

Fig. 3 Embryological differentiation pathways of VSMCs and ECs

factor, $\alpha$-thrombin, factor Xa, angiotensin II, endothelin-1, and unsaturated lypophosphatidic acid [45]. On the other hand, the contractile phenotype is promoted by the expression of heparin, TGF $\beta$, and angiotensin II and IGF1 [45, 46]. Generally, VSMC phenotypic plasticity and the switch from contractile to synthetic phenotype are characterized by reduced expression of VSMC-selective differentiation markers, such as Calponin (CNN1), Transgelin (TAGLN), Caldesmon (CALD1), SMA, or smoothelin. Further they show increased proliferation rate, increased migration, and the synthesis of extracellular matrix (ECM) components required for vascular repair (Fig. 4) [44].

In 2016, Yang et al. published a method that allows the differentiation of phenotype-specific VSMCs [47]. First, iPSCs are split 2 days prior to differentiation [47]. For differentiation into the synthetic phenotype, progenitors are treated with VEGF-A and FGF2 for 7 days in the absence (d3-7) or presence (d7-10) of B27 supplement [47]. From day 10, these cells were then treated with PDGF-beta and TGF-beta for 4 days to specify synthetic VSMC properties. Purification of
iPSC-derived synthetic VSMCs was performed using $4 \mathrm{mM}$ lactate. For the differentiation into VSMCs with the contractile phenotype, cells were treated with VEGF-A and FGF2 in the absence of B27 for 4 days. Starting as early as from day 7 , PDGF-beta and TGF-beta was applied to induce VSMCs into the contractile phenotype. Purification was again performed on day 14 with $4 \mathrm{mM}$ lactate [47]. Purification of cells increased the amount of SMA+ cells from approximately $40 \%$ to $95 \%$ [47]. Further, the VSMC markers MHC11, CNN1, and TAGLN, were expressed significantly more in contractile compared with synthetic iPSC-derived VSMCs [47].

The contractile phenotype of VSMCs is predominantly found in the tunica media, which is required for the regulation of vascular tone [48]. Contractile VSMCs are characterized by a functional contractile apparatus, low proliferation rate, low connective tissue, and a response mechanism to neurotransmitters such as acetylcholine and norepinephrine $[42,45]$. The synthetic phenotype, however, is characterized by fibroblast-like morphology, excretion of high amounts of ECM, high proliferation rate, and decreased expression of contractile proteins [42, 45, 49]. 
Contractile VSMC

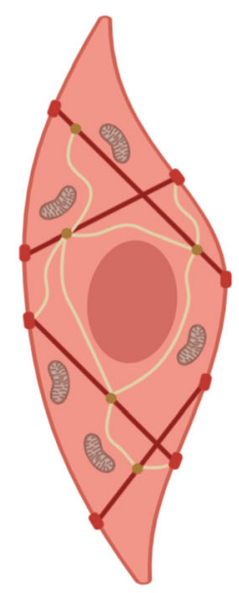

Phenotypic switch

EC-SMC Crosstalk
- diffusible factors, NO
- EC/SMC contact
- control of vascular permeability
Injury/Atherogenic Stimuli
- lipids/lipid products
- mechanical trauma
- toxins, ROS, chemicals
- inflammatory mediators/cells
SMC-SMC Interactions
- cell/cell interaction
- autocrine factors
Neuronal Effects
- neurotransmitters
- control of vascular tone

Fig. 4 VSMC phenotypic switch between contractile and synthetic phenotype. Various factors contribute to VSMC phenotypic switch, including cell interactions between ECs and SMCs, mechanical forces,

It remains unclear as to whether VSMC phenotypic plasticity contributes to the onset and progression of vascular diseases, such as atherosclerosis [42, 44, 48]. However, it is known that vascular calcification or mineralization contribute to atherosclerosis, and takes place within the plaque and the fibrous cap, as well as in the media [50].

VSMCs are often involved, if not the leading force, in this process [51-53]. As primary VSMCs quickly lose their contractile properties in vitro [43], it is necessary to be able to differentiate VSMCs in an origin-specific manner from PSCs. Any in vitro findings therefore need to be verified in an in vivo model [44]. Further, primary VSMCs lose their proliferative potential with increasing donor age, therefore they are not always a reliable source of cells [43]. Taking all this into consideration, PSC-derived VSMCs are the best option to generate high cell numbers in vitro, eliminate patient risk, and reduce loss of contractility $[43,44]$. Further, the in vitro differentiation of PSCs into VSMCs from different origins are important to examine their contribution to disease progression and outcome. 3D organoid models represent the next advancement in the field, as they resemble the structural and functional complexity of the vascular system including cell-cell interactions.

\section{Vascular Organoids}

As described earlier, various 3D models of organs and tissues have been developed within the last 10 to 15 years. This

\section{Synthetic \\ VSMC}

Extracellular Matrix

- connective tissue components

- adhesion molecules/integrins

- composition of ECM

- MMPs

Mechanical Forces

- active stress/strain

- hemodynamic forces

- passive stretch

Inductors

- growth factors/inhibitors

- contractile agonists

- other differentiation factors

$\underline{\mathrm{O}}_{2}$ Tension

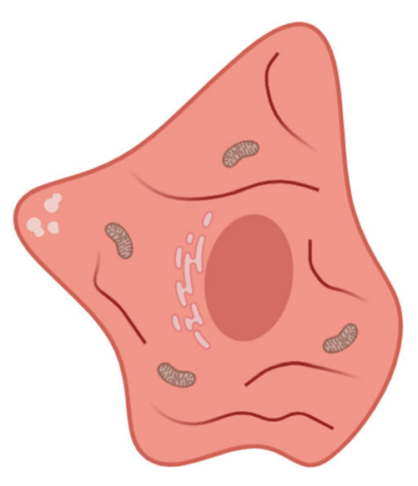

ECM composition, oxygen $\left(\mathrm{O}_{2}\right)$, neuronal effects, injury, and inflammation

includes the brain, lung, liver, and intestines. These 3D cell culture models not only mimic embryonic development, but also better resemble the physiological situation than 2D systems. Three protocols were developed within the last 5 years to differentiate vascular cells from iPSCs and pave the path for their use in 3D grafts [54]. All three protocols successfully lead to the generation of vascular ECs or VSMCs via different pathways. However, all of the three protocols display weaknesses, such as missing capability in mechanical durability, missing VSMCs, cell heterogeneity, and immaturity of cells [54]. Therefore, they were inadequate for use in 3D grafts [54]. Another approach towards 3D engineered vascular tissue was made by constructing tissue-engineered vascular grafts (TEVGs) which are basically artificial blood vessel constructs embedded in matrix. Different cell types, such as stromal cells, various ECs, and VSMCs were co-cultured in a hydrogel and formed vessel-like structures that are perfusable [54]. Even though the TEVGs showed some more levels of physiological properties than the before-mentioned protocols, they were still not applicable in clinics as they showed low plasticity and few connections to the host blood system [54].

Additionally, two models were developed potentially suggesting clinical application of human iPSC-derived vascular cells. In 2011, Lin and colleagues developed a model for human vascular networks against anemia. Endothelial colonyforming cells (ESFCs) and mesenchymal stem cells (MSCs) from anemia patients were co-cultured in collagen/fibrinogen hydrogels and injected subcutaneously in mice. The grafts successfully produced networks of perfused blood vessels 
expressing human CD31. However, the aim was to investigate whether genetically engineered grafts could cure anemia. Therefore, human erythropoietin was overexpressed in the grafts and implanted in a mouse anemia model [55]. The gene edited grafts successfully formed vessel networks and expressed and secreted erythropoietin into the bloodstream of mice [55]. Further, using a tetracyclin system it was possible to induce gene expression of erythropoietin in the grafts with oral supplementation of doxycyclin in mice. Mice with access to doxycyclin recovered faster after radiation than control mice, showing that implants maintained the ability to produce erythropoietin even after high radiation doses [55]. Further, a mouse model for renal failure was treated with the engineered grafts showing a fast recovery after radiation and doxycyclin treatment even with insufficient renal function. Most importantly, they reported a confined cellular engraftment, as human ECFCs or MSCs could not be detected elsewhere in the mice. In summary, Lin and colleagues managed to achieve a correction of anemia in a mouse model using human endothelial-based vascular grafts with erythropoietin overexpression after only 1 week. This method combines the advantages of ex vivo gene editing and specific cellular engraftments. The authors suggest that their model might lead to the development of an alternative treatment of chronic anemia patients without the need of repetitive, regular injections and therefore, also cost reduction in medical treatment of anemia [55].

Only very recently, Neumeyer and colleagues published another 3D model made of human iPSC-derived ECs of hemophilia A patients that can be transplanted into the subcutaneous site [56]. Hemophilia A is a bleeding disorder caused by dysfunctional coagulation-factor 8 (F8). As F8 is a comparably large gene it is hardly packed into common vectors for gene therapy. Therefore, Neumeyer and colleagues produced iPSC-derived ECs from hemophilia A patients and delivered the functional F8 gene into these ECs. Subsequently, xenografts of the genetically engineered ECs were injected into the subcutaneous space of hemophilic mice. The hemophilic grafts carrying the functional F8 gene formed perfused vessel networks and their lumens were filled with mouse erythrocytes, showing connection to the host blood system [56]. The F8 overexpressing ECs also rescued the clotting deficiency in hemophilic mice, and increased activity of F8 was detected pointing towards efficient release of $\mathrm{F} 8$ from the grafts in vivo [56]. However, the model also has its weaknesses. The subcutaneous application of human ECs in mice is only stable for 1 week. Longer duration of the experimental setting lead to replacement of human ECs by mouse ECs. Therefore, longterm studies testing EC engraftment in other tissues need to be performed to determine the most suitable site of application to guarantee efficacy over long periods of time for clinical applications. Nevertheless, Neumeyer and colleagues were able to rebuild a hemostasis comparable to healthy animals in only
1 week. Both aforementioned protocols show successful 3D models of vascular cell implants that were able to, at least in an animal model, restore two diseases of the hemostatic system and perspectively offer the basis for the development of gene therapy and even personalized therapy by vascular graft delivery.

Recently, Wimmer and colleagues published the first PSCderived vascular organoid model [9]. Briefly, human PSCs were differentiated in vitro into mesodermal cells, and then VEGF-A and forskolin were applied for 2 days to induce the vascular lineage [9]. To create a 3D model, Wimmer and colleagues used Matrigel/Collagen hydrogels to stimulate vessel sprouting. The resulting vascular networks were then isolated from the hydrogel and cultured in round-bottom, low binding plates to promote 3D vessel organoid formation [9]. The vascular organoids consisted of ECs and Pericytes (PCs). This protocol allowed the culture of $3 \mathrm{D}$ vascular organoids in 96 well plates over a long period, and showed significant lumen formation [54]. After transplantation into the mouse kidney, the organoids connected with the host vessels, allowing perfusion. This provided evidence that the PSCderived vascular organoids were functional [9]. However, some important measures are missing that are required for good manufacturing practices in order to use the organoids in clinical approaches. Cellular heterogeneity was not assessed and might combat the reproducibility of the method. Further, a control checkpoint is missing that would be required for clinical application [54].

The application possibilities of the organoids are numerous, starting from investigating high blood pressure and shear stress effects on ECs, to the effects of inflammatory factors on SMC behaviour and phenotype switching, or cross-talk between ECs and VSMCs during stress. Furthermore, transplantation of pre-vascularized tissues could accelerate wound healing by promoting the connection of the transplant with the surrounding host tissue [58]. In future, it would be advantageous to adapt the vascular organoids to contain VSMCs beneath the already established cell types of the vascular system ECs and PCs to better resemble the physiological environment.

Recently, other PSC-derived organoid models have been used to investigate disease onset, progression, and pathology. For example, human mini-brains have been used to analyse the genetics of microcephaly, including its connection to the Zika-virus [59]. Very recently, researchers used PSC-derived organoids to investigate the infection strategy of the SARS$\mathrm{CoV} 2$ virus for identification of potential drug candidates [59]. Human organoids models have already been used to investigate infectious diseases, cystic fibrosis, and cancer [59], and the list of applications is still growing.

In the field of cardiovascular research, 3D cell culture systems, such as human organoids, closely mimic the complex in vivo physiology of the vascular system, allowing the 
Table 1 Summary of publications, methods including the growth factors that have been used, disadvantages and advantages and performed analysis

\begin{tabular}{|c|c|c|c|c|c|c|}
\hline Year & Cells & Format & Growth factors & Analyses & Advantages & Disadvantages \\
\hline $2020[54]$ & $\begin{array}{l}\text { NCSCs } \\
(\mathrm{ECs}) \\
\text { VSMCs }\end{array}$ & grafts & bFGF, TGFb1 & $\begin{array}{l}\text { NCSCs: P57+, NES+, } \\
\text { VIM+,HNK1+, staining: } \\
\text { phalloidin + vinculin for } \\
\text { cytoskeleton organization in } \\
\text { response to substrate stiffness; } \\
\text { SMA+ after TGFb treatment; } \\
\text { grafts: H\&E staining, Verhoeff's } \\
\text { staining, NuMA+, MHC+, } \\
\text { Instron mechanical test; CD31+ } \\
\text { staining: EC differentiation } \\
\text { capacity from NCSCs }\end{array}$ & $\begin{array}{l}\text { VSMCs with enhanced } \\
\text { mechanical properties }\end{array}$ & $\begin{array}{l}\text { no lineage } \\
\text { specification; } \\
\text { heterogeneity }\end{array}$ \\
\hline 2019 [57] & ECs & monolayer & $\begin{array}{l}\text { VEGF, bFGF, shear } \\
\text { stress/flow }\end{array}$ & $\begin{array}{l}\text { after shear stress: qPCR: CD309+, } \\
\text { CD144+, arterial markers: } \\
\text { EPHB2+, NRP1+, staining: } \\
\text { CD13+, vWF+, CD144+; tube } \\
\text { formation capacity in matrigel }\end{array}$ & $\begin{array}{l}\text { better maturation of ECs; } \\
\text { different reactions by } \\
\text { arterial/veinal ECs }\end{array}$ & $\begin{array}{l}\text { lack of VSMCs in the } \\
\text { model }\end{array}$ \\
\hline 2019 [9] & $\begin{array}{l}\text { ECs } \\
\text { PCs }\end{array}$ & organoid & $\begin{array}{l}\text { CHIR99021, BMP-4, } \\
\text { VEGF-A, forskolin }\end{array}$ & $\begin{array}{l}\text { staining: CD31+, UEA-I+, } \\
\text { PDGFRb+, SMA+; perfusion: } \\
\text { FITC-Dextran, MRI of } \\
\text { transplants }\end{array}$ & $\begin{array}{l}\text { 3D vessel structure, } \\
\text { lumen, perfusable }\end{array}$ & $\begin{array}{l}\text { lack of VSMCs in the } \\
\text { model; missing } \\
\text { GMP standards }\end{array}$ \\
\hline 2017 [37] & ECs & monolayer & $\begin{array}{l}\text { Activin A, bFGF, } \\
\text { BMP-4, } \\
\text { 8bromo-cAMP, } \\
\text { VEGF, EGF }\end{array}$ & $\begin{array}{l}\text { sorting for CD31+, CD144+ and } \\
\text { CD309+; stimulation method and } \\
\text { stimulation-elimination method; } \\
\text { ECs show tube formation capac- } \\
\text { ity in matrigel; ECs are capable in } \\
\text { AcLDL uptake }\end{array}$ & $\begin{array}{l}\text { sorting for purity; first } \\
\text { description of the } \\
\text { stimulation method and } \\
\text { stimulation-elimination } \\
\text { method; functional ECs }\end{array}$ & complex protocol \\
\hline 2017 [38] & $\begin{array}{l}\text { ECs } \\
\text { CMCs }\end{array}$ & monolayer & $\begin{array}{l}\text { CHIR99021, Activin } \\
\text { A, VEGF, BMP-4, } \\
\text { bFGF }\end{array}$ & $\begin{array}{l}\text { FACS analysis for CD31+, CD34+ } \\
\text { and CD144+; hemogenic } \\
\text { mesoderm derived ECs have the } \\
\text { capacity for erythroid and } \\
\text { myeloid lineages based on } \\
\text { hematopoiesis assays; EC lumen } \\
\text { formation in collagen gel }\end{array}$ & $\begin{array}{l}\text { pure population; directed } \\
\text { differentiation due to } \\
\text { polarized mesoderm } \\
\text { induction; no sorting } \\
\text { needed }\end{array}$ & $\begin{array}{l}\text { conditions are not } \\
\text { chemically defined, } \\
\text { B-27 supplement, } \\
\text { and recombinant } \\
\text { proteins }\end{array}$ \\
\hline 2016 [47] & VSMCs & monolayer & $\begin{array}{l}\text { VEGF-A, bFGF, } \\
\text { PDGF-BB, TGFb1, } \\
\text { B-27 }\end{array}$ & $\begin{array}{l}\text { contractile: MHC11+, CNN1+, } \\
\text { TAGLN+, synthetic: COL-I+, } \\
\text { CX43+, VIM+; proliferation \& } \\
\text { migration increased in synthetic } \\
\text { SMCs: contraction as carbachol } \\
\text { treatment response: increased in } \\
\text { contractile SMCs }\end{array}$ & $\begin{array}{l}\text { phenotype (synthetic \& } \\
\text { contractile) specific } \\
\text { VSMCs }\end{array}$ & $\begin{array}{l}\text { heterogeneity of } \\
\text { VSMCs }\end{array}$ \\
\hline 2015 [36] & $\begin{array}{l}\text { ECs } \\
\text { VSMCs }\end{array}$ & monolayer & $\begin{array}{l}\text { CP21R7, BMP-4, } \\
\text { VEGF, forskolin, } \\
\text { PDGF-BB, Acticin } \\
\text { A }\end{array}$ & $\begin{array}{l}\text { endodermal progenitors: SOX17+; } \\
\text { ECs sorted for: CD144+, } \\
\text { CD309+, CD31+, CD34+, } \\
\text { CD105+; CD43-/CD45-; } \\
\text { VSMCs: PDGFR+, } \\
\text { alpha-SMA+, myosin IIb+: } \\
\text { transcriptomics reflected } \\
\text { vascular cells similar to primary } \\
\text { cells; tube formation capacity }\end{array}$ & $\begin{array}{l}\text { checkpoint control by } \\
\text { FACS sorting ECs; } \\
\text { high purity VSMCs }\end{array}$ & $\begin{array}{l}\text { heterogeneity of ECs; } \\
\text { subset of ECs } \\
\text { expressed SMA, few } \\
\text { mechanical } \\
\text { endurance }\end{array}$ \\
\hline 2014 [41] & VSMCs & monolayer & $\begin{array}{l}\text { Activin A, bFGF, } \\
\text { SB431542, } \\
\text { LY294002, bFGF, } \\
\text { BMP-4, PDGF-BB, } \\
\text { TGFb1 }\end{array}$ & $\begin{array}{l}\text { early mesoderm: brachyury+, } \\
\text { NE-lineage: PAX6+, NES+; } \\
\text { PM-lineage: TCF1+; } \\
\text { LM-lineage: CD309+; SMCs: } \\
\text { CNN1+, TAGLN+, MYH11+ }\end{array}$ & $\begin{array}{l}\text { checkpoints for } \\
\text { mesodermal lineage; } \\
\text { directed, lineage } \\
\text { specific differentiation } \\
\text { of iPSCs into VSMCs }\end{array}$ & time-consuming \\
\hline $2014[35]$ & $\begin{array}{l}\text { ECs } \\
\text { PCs }\end{array}$ & monolayer & $\begin{array}{l}\text { Activin A, BMP-4, } \\
\text { VEGF, CHIR99021, } \\
\text { SB43152, bFGF }\end{array}$ & $\begin{array}{l}\text { sorting for CD31+; IF positive for } \\
\text { CD144, CD31, vWF and } \\
\text { LYVE1; first description of } \\
\text { simultaneous derivation of ECs } \\
\text { and pericytes; in a zebrafish } \\
\text { xenograft model ECs were able }\end{array}$ & $\begin{array}{l}\text { sorting for purity; } \\
\text { functional ECs; } \\
\text { validation in in vivo } \\
\text { model }\end{array}$ & $\begin{array}{l}\text { generated ECs express } \\
\text { less arterial and } \\
\text { venous markers than } \\
\text { HUVECs; ECs } \\
\text { express lymphatic } \\
\text { markers }\end{array}$ \\
\hline
\end{tabular}

to incorporate into developing as well as established vasculature 
Table 1 (continued)

\begin{tabular}{|c|c|c|c|c|c|c|}
\hline Year & Cells & Format & Growth factors & Analyses & Advantages & Disadvantages \\
\hline 2013 [30] & ECs & EB & $\begin{array}{l}\text { bFGF, Activin A, } \\
\text { BMP-4, VEGF, } \\
\text { apo-transferrin, } \\
\text { insulin, EGF, IGF-1, } \\
\text { hydrocortisone, } \\
\text { retinoic acid }\end{array}$ & $\begin{array}{l}\text { sorting for CD309+; IF positive for } \\
\text { CD31, CD144, eNOS, and } \\
\text { vWF; ECs are capable in } \\
\text { DiI-ac-LDL uptake; ECs show } \\
\text { tube formation capacity in } \\
\text { matrigel }\end{array}$ & $\begin{array}{l}\text { sorting for purity; } \\
\text { functional ECs }\end{array}$ & $\begin{array}{l}\text { low efficiency: many } \\
\text { inductors are needed }\end{array}$ \\
\hline 2013 [32] & ECs & EB & $\begin{array}{l}\text { comercial EC growth } \\
\text { supplement }\end{array}$ & $\begin{array}{l}\text { sorting for CD144+; IF positive for } \\
\text { CD144, CD309, and CD141, } \\
\text { eNOS, Ang2, vWF; ECs are } \\
\text { capable in AcLDL uptake; ECs } \\
\text { show tube formation capacity in } \\
\text { matrigel; proinflammatory } \\
\text { stimuli induce an activated } \\
\text { proinflammatory phenotype }\end{array}$ & $\begin{array}{l}\text { functional ECs; } \\
\text { proinflammatory } \\
\text { testing }\end{array}$ & $\begin{array}{l}\text { low efficiency; } \\
\text { heterogeneity; } \\
\text { undirected } \\
\text { differentiation }\end{array}$ \\
\hline 2012 [31] & $\begin{array}{l}\text { ECs } \\
\text { HPCs }\end{array}$ & EB & $\begin{array}{l}\text { BMP-4, PD98059, } \\
\text { SCF, VEGF, Flt3L, } \\
\text { bFGF, IL-3, IL-6 }\end{array}$ & $\begin{array}{l}\text { hBMMSC-derived iPSCs to produce } \\
\text { CD34+ progenitor; sorting for } \\
\text { CD34+; IF positive for CD31 and } \\
\text { CD144; ECs show tube formation } \\
\text { capacity in matrigel }\end{array}$ & functional ECs & $\begin{array}{l}\text { low efficiency; } \\
\text { heterogeneity; many } \\
\text { inductors are needed }\end{array}$ \\
\hline 2011 [28] & ECs & EB & VEGF, bFGF & $\begin{array}{l}\text { sorting for CD31+; ECs are } \\
\text { capable in DiI-ac-LDL uptake, } \\
\text { ECs show tube formation ca- } \\
\text { pacity in matrigel }\end{array}$ & functional ECs & $\begin{array}{l}\text { low efficiency; } \\
\text { heterogeneity }\end{array}$ \\
\hline 2011 [29] & ECs & EB & BMP-4, VEGF & $\begin{array}{l}\text { sorting for CD31+; IF positive for } \\
\text { CD309, CD31, CD144, and } \\
\text { eNOS; in vivo application of } \\
\text { iPSCs in a murine model, ECs } \\
\text { are capable in AcLDL uptake }\end{array}$ & $\begin{array}{l}\text { functional ECs; in vivo } \\
\text { application of iPSCs in } \\
\text { a murine model }\end{array}$ & $\begin{array}{l}\text { low efficiency; } \\
\text { heterogeneity }\end{array}$ \\
\hline 2010 [34] & ECs & monolayer & $\begin{array}{l}\text { N2 supplement, B27 } \\
\text { supplement, } \\
\text { StemPro-34 SFM, } \\
\text { VEGF }\end{array}$ & $\begin{array}{l}\text { sorting for CD309+ and CD144+; } \\
\text { iPSC-derived ECs have a greater } \\
\text { wound healing capacity and ox- } \\
\text { idative stress tolerance than } \\
\text { HAECs; IF positive for eNOS, } \\
\text { CD31 and CD144 }\end{array}$ & functional ECs & $\begin{array}{l}\text { low efficiency; use of } \\
\text { mouse feeder cells; } \\
\text { undirected } \\
\text { differentiation }\end{array}$ \\
\hline 2010 [33] & $\begin{array}{l}\text { ECs } \\
\text { VSMCs }\end{array}$ & monolayer & $\begin{array}{l}\text { PD98059, BMP-4, } \\
\text { VEGF-A, bFGF }\end{array}$ & $\begin{array}{l}\text { sorting for CD34+; direct } \\
\text { differentiation based on } \\
\text { mesoderm induction; ECs show } \\
\text { CD31 and CD105 expression, IF } \\
\text { positive for CD31, VWF, } \\
\text { CD144, ANG2, and CD309, } \\
\text { ECs show tube formation } \\
\text { capacity in matrigel; ECs are } \\
\text { capable in AcLDL uptake }\end{array}$ & $\begin{array}{l}\text { feeder- and serum-free } \\
\text { system; direct differen- } \\
\text { tiation; functional ECs }\end{array}$ & low efficiency \\
\hline 2009 [40] & VSMCs & monolayer & retinoic acid & $\begin{array}{l}\text { staining: SMMHC+, alpha-SMA+; } \\
\text { sorting SMMHC; qPCR: } \\
\text { MYOCD+, TAGLN+; } \\
\text { alphaSMA+, SMMHC; } \\
\text { carbachol-induced contraction } \\
\text { positive for ca. } 80 \% \text { of cells }\end{array}$ & $\begin{array}{l}\text { fast differentiation of } \\
\text { iPSCs into VSMCs }\end{array}$ & $\begin{array}{l}\text { undirected and } \\
\text { spontaneous } \\
\text { differentiation; } \\
\text { heterogeneity }\end{array}$ \\
\hline 2009 [26] & $\begin{array}{l}\text { ECs } \\
\text { HPs } \\
\text { MLCs }\end{array}$ & co-culture & bFGF, ECGF & $\begin{array}{l}\text { sorting for CD34+, CD31+ and } \\
\text { CD43-; IF positive for CD144; } \\
\text { ECs in FACS analysis positive } \\
\text { for vWF, CD309, CD31, } \\
\text { CD49d, and CD105; ECs show } \\
\text { tube formation capacity in } \\
\text { matrigel }\end{array}$ & $\begin{array}{l}\text { co-culture of various } \\
\text { vascular cell types }\end{array}$ & $\begin{array}{l}\text { very low efficiency; } \\
\text { heterogeneity; } \\
\text { contamination due to } \\
\text { co-culture }\end{array}$ \\
\hline 2009 [27] & $\begin{array}{l}\text { ECs } \\
\text { MCs }\end{array}$ & co-culture & VEGF & $\begin{array}{l}\text { sorting for CD309+ and CD144+; } \\
\text { ECs formed a network-like } \\
\text { structure in matrigel; IF positive } \\
\text { for CD31 and eNOs }\end{array}$ & $\begin{array}{l}\text { co-culture of various } \\
\text { vascular cell types }\end{array}$ & $\begin{array}{l}\text { very low efficiency; } \\
\text { heterogeneity; } \\
\text { contamination due to } \\
\text { co-culture }\end{array}$ \\
\hline
\end{tabular}

$M C s$ mural cells, $H P s$ hematopoietic progenitors, $M L C s$ mesenchymal lineage cells, $H P C$ hematopoietic cells, $P C s$ pericytes, $E B$ embryoid bodies 
investigation of genetics, function, and disease pathophysiology. Use of these model systems is an ideal alternative to reduce the use of experimental animals and their derivatives and allows us to examine human pathophysiology.

However, the field of human iPS-derived organoids is still very young. Various difficulties occurring along the way must be addressed in order to make this method reliable and clinically applicable. First, the cell heterogeneity within iPSC-lines and even clones have to be tackled, and heterogeneities within and between the organoids have to be addressed. Further, the lack of perfusion in vitro is a major obstacle, as perfusion of vessels is needed to get rid of waste, to evenly distribute nutrients, and most important to force EC maturation by shear stress [54]. Additionally, blood components as well as immunological cell types should be considered to be integrated into the organoids to increase translatability and to resemble a more physiological situation. Finally, we propose that the biggest challenge that needs to be addressed first in the organoid research is to replace animal contents. Most protocols rely at least on some kind of animal tissue or components, such as Matrigel or rat collagen [9], decellularized porcine intestine scaffolds [54], or FBS which is still quite common in cell culture labs around the world.

Nevertheless, we believe that iPS-derived vascular organoids hold a great promise in vascular research allowing studies on functional and genetic backgrounds of different disease patterns of coronary artery disease. This technique allows investigations impossible with primary tissue and animal models such as developmental studies on vasculature or high content drug screening on human tissue with an almost unlimited availability.

Author Contributions Anja Trillhaase and Marlon Märtens wrote the majority of the manuscript. Jeanette Erdmann and Zouhair Aherrahrou contributed to the project design, editing and writing of the manuscript, as well as collecting funding.

Funding Open Access funding enabled and organized by Projekt DEAL. This study was funded by the DZHK (German Centre for Cardiovascular Research) and by Fondation Leducq (18CVD02, PlaqOmics).

Data Availability Not applicable.

Code Availability Not applicable.

\section{Declarations}

Ethics Approval Not applicable.

Consent to Participate Not applicable.

Consent for Publication Not applicable.
Conflict of Interest The authors have no conflicts of interest to declare that are relevant to the content of this article.

Open Access This article is licensed under a Creative Commons Attribution 4.0 International License, which permits use, sharing, adaptation, distribution and reproduction in any medium or format, as long as you give appropriate credit to the original author(s) and the source, provide a link to the Creative Commons licence, and indicate if changes were made. The images or other third party material in this article are included in the article's Creative Commons licence, unless indicated otherwise in a credit line to the material. If material is not included in the article's Creative Commons licence and your intended use is not permitted by statutory regulation or exceeds the permitted use, you will need to obtain permission directly from the copyright holder. To view a copy of this licence, visit http://creativecommons.org/licenses/by/4.0/.

\section{References}

1. Takahashi, K., Tanabe, K., Ohnuki, M., Narita, M., Ichisaka, T., Tomoda, K., \& Yamanaka, S. (2007). Induction of pluripotent stem cells from adult human fibroblasts by defined factors. Cell, 131(5), 861-872. https://doi.org/10.1016/j.cell.2007.11.019.

2. Chen, I. Y., Matsa, E., \& Wu, J. C. (2016). Induced pluripotent stem cells: At the heart of cardiovascular precision medicine. Nature Reviews Cardiology, 13(6), 333-349. https://doi.org/10. 1038/nrcardio.2016.36.

3. Alghuwainem, A., Alshareeda, A. T., \& Alsowayan, B. (2019). Scaffold-free 3-D cell sheet technique bridges the gap between 2$\mathrm{D}$ cell culture and animal models. International Journal of Molecular Sciences, 20(19), 4926. https://doi.org/10.3390/ ijms20194926.

4. Edmondson, R., Broglie, J. J., Adcock, A. F., \& Yang, L. (2014). Three-dimensional cell culture systems and their applications in drug discovery and cell-based biosensors. Assay and Drug Development Technologies, 12(4), 207-218. https://doi.org/10. 1089/adt.2014.573.

5. Zimmermann, W.-H., Melnychenko, I., \& Eschenhagen, T. (2004). Engineered heart tissue for regeneration of diseased hearts. Biomaterials, 25(9), 1639-1647. https://doi.org/10.1016/S01429612(03)00521-0.

6. Dye, B. R., Hill, D. R., Ferguson, M. A., Tsai, Y. H., Nagy, M. S., Dyal, R., Wells, J. M., Mayhew, C. N., Nattiv, R., Klein, O. D., White, E. S., Deutsch, G. H., Spence, J. R. (2015). In vitro generation of human pluripotent stem cell derived lung organoids. Elife, 4, e05098. https://doi.org/10.7554/eLife.05098.

7. Kauffman, A. L., Ekert, J. E., Gyurdieva, A. V., Rycyzyn, M. A., \& Hornby, P. J. (2015). Directed differentiation protocols for successful human intestinal organoids derived from multiple induced pluripotent stem cell lines. Stem Cell Biology and Research, 2(1), 1. https://doi.org/10.7243/2054-717X-2-1.

8. Lancaster, M. A., \& Knoblich, J. A. (2014). Generation of cerebral organoids from human pluripotent stem cells. Nature Protocols, 9(10), 2329-2340. https://doi.org/10.1038/nprot.2014.158.

9. Wimmer, R. A., Leopoldi, A., Aichinger, M., Kerjaschki, D., \& Penninger, J. M. (2019). Generation of blood vessel organoids from human pluripotent stem cells. Nature Protocols, 14(11), 30823100. https://doi.org/10.1038/s41596-019-0213-z.

10. Terryn, J., Tricot, T., Gajjar, M., \& Verfaillie, C. (2018). Recent advances in lineage differentiation from stem cells: hurdles and opportunities? F1000Research, 7, 220. https://doi.org/10.12688/ f1000research.12596.1.

11. Libby, P., Bornfeldt, K. E., \& Tall, A. R. (2016). Atherosclerosis successes, surprises, and future challenges. Circulation Research, 
118(4), 531-534. https://doi.org/10.1161/CIRCRESAHA.116. 308334.

12. Ritman, E., \& Lerman, A. (2007). The dynamic vasa vasorum. Cardiovascular Research, 75(4), 649-658. https://doi.org/10. 1016/j.cardiores.2007.06.020.

13. Stocker, R., \& Keaney, J. F. (2004). Role of oxidative modifications in atherosclerosis. Physiological Reviews, 84(4), 1381-1478. https://doi.org/10.1152/physrev.00047.2003.

14. Witter, K., Tonar, Z., \& Schöpper, H. (2017). How many layers has the adventitia? - structure of the arterial tunica Externa revisited. Anatomia, Histologia, Embryologia, 46(2), 110-120. https://doi. org/10.1111/ahe.12239.

15. Saracoglu, A., \& Tetik, S. (2019). Trauma-induced apoptosis of endothelial cells. Journal of Medicinal and Chemical Sciences, 2(3), 92-95. https://doi.org/10.26655/jmchemsci.2019.4.4.

16. Gimbrone, M. A., \& García-Cardeña, G. (2013). Vascular endothelium, hemodynamics, and the pathobiology of atherosclerosis. Cardiovascular Pathology, 22(1), 9-15. https://doi.org/10.1016/j. carpath.2012.06.006.

17. Lange, C., Storkebaum, E., de Almodóvar, C. R., Dewerchin, M., \& Carmeliet, P. (2016). Vascular endothelial growth factor: A neurovascular target in neurological diseases. Nature Reviews Neurology, 12(8), 439-454. https://doi.org/10.1038/nrneurol. 2016.88.

18. Madden, J. A. (2012). Role of the vascular endothelium and plaque in acute ischemic stroke. Neurology, 79(Issue 13, Supplement 1), S58-S62. https://doi.org/10.1212/WNL.0b013e3182695836.

19. Hockemeyer, D., \& Jaenisch, R. (2016). Induced pluripotent stem cells meet genome editing. Cell Stem Cell, 18(5), 573-586. https:// doi.org/10.1016/j.stem.2016.04.013.

20. Liu, X., Li, W., Fu, X., \& Xu, Y. (2017). The immunogenicity and immune tolerance of pluripotent stem cell derivatives. Frontiers in Immunology, 8, 645. https://doi.org/10.3389/fimmu.2017.00645.

21. Vargas-Valderrama, A., Messina, A., Mitjavila-Garcia, M. T., \& Guenou, H. (2020). The endothelium, a key actor in organ development and hPSC-derived organoid vascularization. Journal of Biomedical Science, 27(1), 67. https://doi.org/10.1186/s12929020-00661-y.

22. Kaufman, D. S., Hanson, E. T., Lewis, R. L., Auerbach, R., \& Thomson, J. A. (2001). Hematopoietic colony-forming cells derived from human embryonic stem cells. Proceedings of the National Academy of Sciences, 98(19), 10716-10721. https://doi. org/10.1073/pnas.191362598.

23. Chadwick, K., Wang, L., Li, L., Menendez, P., Murdoch, B., Rouleau, A., \& Bhatia, M. (2003). Cytokines and BMP-4 promote hematopoietic differentiation of human embryonic stem cells. Blood, 102(3), 906-915. https://doi.org/10.1182/blood-2003-030832.

24. Levenberg, S., Golub, J. S., Amit, M., Itskovitz-Eldor, J., \& Langer, R. (2002). Endothelial cells derived from human embryonic stem cells. Proceedings of the National Academy of Sciences, 99(7), 4391-4396. https://doi.org/10.1073/pnas.032074999.

25. Yang, L., Soonpaa, M. H., Adler, E. D., Roepke, T. K., Kattman, S. J., Kennedy, M., Henckaerts, E., Bonham, K., Abbott, G. W., Linden, R. M., Field, L. J., \& Keller, G. M. (2008). Human cardiovascular progenitor cells develop from a KDR+ embryonic-stemcell-derived population. Nature, 453(7194), 524-528. https://doi. org/10.1038/nature06894.

26. Choi, K.-D., Yu, J., Smuga-Otto, K., Salvagiotto, G., Rehrauer, W., Vodyanik, M., Thomson, J., \& Slukvin, I. (2009). Hematopoietic and endothelial differentiation of human induced pluripotent stem cells. Stem Cells, 27(3), 559-567. https://doi.org/10.1002/stem. 20080922.

27. Taura, D., Sone, M., Homma, K., Oyamada, N., Takahashi, K., Tamura, N., Yamanaka, S., \& Nakao, K. (2009). Induction and isolation of vascular cells from human induced pluripotent stem
cells-Brief report. Arteriosclerosis, Thrombosis, and Vascular Biology, 29(7), 1100-1103. https://doi.org/10.1161/ATVBAHA. 108.182162.

28. Li, Z., Hu, S., Ghosh, Z., Han, Z., \& Wu, J. C. (2011). Functional characterization and expression profiling of human induced pluripotent stem cell- and embryonic stem cell-derived endothelial cells. Stem Cells and Development, 20(10), 1701-1710. https://doi.org/ $10.1089 /$ scd.2010.0426.

29. Rufaihah, A. J., Huang, N. F., Jamé, S., et al. (2011). Endothelial cells derived from human iPSCS increase capillary density and improve perfusion in a mouse model of peripheral arterial disease. Arteriosclerosis, Thrombosis, and Vascular Biology, 31(11), e72e79. https://doi.org/10.1161/ATVBAHA.111.230938.

30. White, M. P., Rufaihah, A. J., Liu, L., Ghebremariam, Y. T., Ivey, K. N., Cooke, J. P., \& Srivastava, D. (2013). Limited gene expression variation in human embryonic stem cell and induced pluripotent stem cell-derived endothelial cells. Stem Cells, 31(1), 92-103. https://doi.org/10.1002/stem.1267.

31. Xu, Y., Liu, L., Zhang, L., et al. (2012). Efficient commitment to functional $\mathrm{CD} 34+$ progenitor cells from human bone marrow mesenchymal stem-cell-derived induced pluripotent stem cells. Rameshwar P, ed. PLOS ONE, 7(4), e34321. https://doi.org/10. 1371/journal.pone.0034321.

32. Adams, W. J., Zhang, Y., Cloutier, J., Kuchimanchi, P., Newton, G., Sehrawat, S., Aird, W. C., Mayadas, T. N., Luscinskas, F. W., \& García-Cardeña, G. (2013). Functional vascular endothelium derived from human induced pluripotent stem cells. Stem Cell Reports, 1(2), 105-113. https://doi.org/10.1016/j.stemcr.2013.06. 007.

33. Park, S.-W., Koh, Y. J., Jeon, J., et al. (2010). Efficient differentiation of human pluripotent stem cells into functional CD34 progenitor cells by combined modulation of the MEK/ERK and BMP4 signaling pathways. Blood, 116(25), 11.

34. Homma, K., Sone, M., Taura, D., Yamahara, K., Suzuki, Y., Takahashi, K., Sonoyama, T., Inuzuka, M., Fukunaga, Y., Tamura, N., Itoh, H., Yamanaka, S., \& Nakao, K. (2010). Sirt1 plays an important role in mediating greater functionality of human ES/iPS-derived vascular endothelial cells. Atherosclerosis, 212(1), 42-47. https://doi.org/10.1016/j.atherosclerosis.2010.04.021.

35. Orlova, V. V., Drabsch, Y., Freund, C., Petrus-Reurer, S., van den Hil, F. E., Muenthaisong, S., Dijke, P., \& Mummery, C. L. (2014). Functionality of endothelial cells and Pericytes from human pluripotent stem cells demonstrated in cultured vascular plexus and Zebrafish Xenografts. Arteriosclerosis, Thrombosis, and Vascular Biology, 34(1), 177-186. https://doi.org/10.1161/ATVBAHA.113. 302598.

36. Patsch, C., Challet-Meylan, L., Thoma, E. C., Urich, E., Heckel, T., O’Sullivan, J. F., Grainger, S. J., Kapp, F. G., Sun, L., Christensen, K., Xia, Y., Florido, M. H. C., He, W., Pan, W., Prummer, M., Warren, C. R., Jakob-Roetne, R., Certa, U., Jagasia, R., Freskgård, P. O., Adatto, I., Kling, D., Huang, P., Zon, L. I., Chaikof, E. L., Gerszten, R. E., Graf, M., Iacone, R., \& Cowan, C. A. (2015). Generation of vascular endothelial and smooth muscle cells from human pluripotent stem cells. Nature Cell Biology, 17(8), 994-1003. https://doi.org/10.1038/ncb3205.

37. Ikuno, T., Masumoto, H., Yamamizu, K., et al. (2017). Efficient and robust differentiation of endothelial cells from human induced pluripotent stem cells via lineage control with VEGF and cyclic AMP. Rajasingh J, ed. PLOS ONE, 12(3), e0173271. https://doi. org/10.1371/journal.pone.0173271.

38. Palpant, N. J., Pabon, L., Friedman, C. E., Roberts, M., Hadland, B., Zaunbrecher, R. J., Bernstein, I., Zheng, Y., \& Murry, C. E. (2017). Generating high-purity cardiac and endothelial derivatives from patterned mesoderm using human pluripotent stem cells. Nature Protocols, 12(1), 15-31. https://doi.org/10.1038/nprot. 2016.153. 
39. Misfeldt, A. M., Boyle, S. C., Tompkins, K. L., Bautch, V. L., Labosky, P. A., \& Baldwin, H. S. (2009). Endocardial cells are a distinct endothelial lineage derived from Flk1+ multipotent cardiovascular progenitors. Developmental Biology, 333(1), 78-89. https://doi.org/10.1016/j.ydbio.2009.06.033.

40. Xie, C.-Q., Huang, H., Wei, S., Song, L. S., Zhang, J., Ritchie, R. P., Chen, L., Zhang, M., \& Chen, Y. E. (2008). A comparison of murine smooth muscle cells generated from embryonic versus induced pluripotent stem cells. Stem Cells and Development, 18(5), 741-748. https://doi.org/10.1089/scd.2008.0179.

41. Cheung, C., Bernardo, A. S., Pedersen, R. A., \& Sinha, S. (2014). Directed differentiation of embryonic origin-specific vascular smooth muscle subtypes from human pluripotent stem cells. Nature Protocols, 9(4), 929-938. https://doi.org/10.1038/nprot. 2014.059.

42. Sinha, S., Iyer, D., \& Granata, A. (2014). Embryonic origins of human vascular smooth muscle cells: Implications for in vitro modeling and clinical application. Cellular and Molecular Life Sciences, 71(12), 2271-2288. https://doi.org/10.1007/s00018-0131554-3.

43. Dash, B. C., Jiang, Z., Suh, C., \& Qyang, Y. (2015). Induced pluripotent stem cell-derived vascular smooth muscle cells: Methods and application. The Biochemical Journal, 465(2), 185-194. https://doi.org/10.1042/BJ20141078.

44. Alexander, M. R., \& Owens, G. K. (2012). Epigenetic control of smooth muscle cell differentiation and phenotypic switching in vascular development and disease. Annual Review of Physiology, 74(1), 13-40. https://doi.org/10.1146/annurev-physiol-012110142315.

45. Beamish, J. A., He, P., Kottke-Marchant, K., \& Marchant, R. E. (2010). Molecular regulation of contractile smooth muscle cell phenotype: Implications for vascular tissue engineering. Tissue Engineering. Part B, Reviews, 16(5), 467-491. https://doi.org/10. 1089/ten.teb.2009.0630

46. Hayashi, K., Shibata, K., Morita, T., Iwasaki, K., Watanabe, M., \& Sobue, K. (2004). Insulin receptor Substrate-1/SHP-2 interaction, a phenotype-dependent switching machinery of insulin-like growth factor-I signaling in vascular smooth muscle cells. The Journal of Biological Chemistry, 279(39), 40807-40818. https://doi.org/10. 1074/jbc.M405100200.

47. Yang, L., Geng, Z., Nickel, T., Johnson, C., Gao, L., Dutton, J., Hou, C., \& Zhang, J. (2016). Differentiation of human inducedpluripotent stem cells into smooth-muscle cells: Two novel protocols. PLoS One, 11(1), e0147155. https://doi.org/10.1371/journal. pone. 0147155 .

48. Adam, P. J., Regan, C. P., Hautmann, M. B., \& Owens, G. K. (2000). Positive- and negative-acting Kruppel-like transcription factors bind a transforming growth factor beta control element required for expression of the smooth muscle cell differentiation marker SM22alpha in vivo. The Journal of Biological Chemistry, 275(48), 37798-37806. https://doi.org/10.1074/jbc.M006323200.

49. Rensen, S. S. M., Doevendans, P. A. F. M., \& van Eys, G. J. J. M. (2007). Regulation and characteristics of vascular smooth muscle cell phenotypic diversity. Netherlands Heart Journal, 15(3), 100108 .
50. Lanzer, P., Boehm, M., Sorribas, V., Thiriet, M., Janzen, J., Zeller, T., St Hilaire, C., \& Shanahan, C. (2014). Medial vascular calcification revisited: Review and perspectives. European Heart Journal, 35(23), 1515-1525. https://doi.org/10.1093/eurheartj/ ehu163.

51. Alam, M., Kirton, J. P., Wilkinson, F. L., Towers, E., Sinha, S., Rouhi, M., Vizard, T. N., Sage, A. P., Martin, D., Ward, D. T., Alexander, M. Y., Riccardi, D., \& Canfield, A. E. (2009). Calcification is associated with loss of functional calcium-sensing receptor in vascular smooth muscle cells. Cardiovascular Research, 81(2), 260-268. https://doi.org/10.1093/cvr/cvn279.

52. Balderman, J. A. F., Lee, H.-Y., Mahoney, C. E., Handy, D. E., White, K., Annis, S., Lebeche, D., Hajjar, R. J., Loscalzo, J., \& Leopold, J. A. (2012). Bone morphogenetic protein-2 decreases microRNA-30b and microRNA-30c to promote vascular smooth muscle cell calcification. Journal of the American Heart Association, 1(6), e003905. https://doi.org/10.1161/JAHA.112. 003905.

53. Tintut, Y., Alfonso, Z., Saini, T., Radcliff, K., Watson, K., Boström, K., \& Demer, L. L. (2003). Multilineage potential of cells from the Artery Wall. Circulation, 108(20), 2505-2510. https://doi. org/10.1161/01.CIR.0000096485.64373.C5.

54. Liu, C., Niu, K., \& Xiao, Q. (2020). Updated perspectives on vascular cell specification and pluripotent stem cell-derived vascular organoids for studying vasculopathies. Cardiovascular Research, cvaa313. https://doi.org/10.1093/cvr/cvaa313.

55. Lin, R.-Z., Dreyzin, A., Aamodt, K., Li, D., Jaminet, S. C. S., Dudley, A. C., \& Melero-Martin, J. M. (2011). Induction of erythropoiesis using human vascular networks genetically engineered for controlled erythropoietin release. Blood, 118(20), 5420-5428. https://doi.org/10.1182/blood-2011-08-372946.

56. Neumeyer, J., Lin, R.-Z., Wang, K., Hong, X., Hua, T., Croteau, S. E., Neufeld, E. J., \& Melero-Martin, J. M. (2019). Bioengineering hemophilia A-specific microvascular grafts for delivery of fulllength factor VIII into the bloodstream. Blood Advances, 3(24), 4166-4176. https://doi.org/10.1182/bloodadvances.2019000848.

57. Huang, Y., Chen, X., Che, J., Zhan, Q., Ji, J., \& Fan, Y. (2019). Shear stress promotes arterial endothelium-oriented differentiation of mouse-induced pluripotent stem cells. Stem Cells International. https://doi.org/10.1155/2019/1847098.

58. Markou, M., Kouroupis, D., Badounas, F., Katsouras, A., Kyrkou, A., Fotsis, T., Murphy, C., \& Bagli, E. (2020). Tissue engineering using vascular Organoids from human pluripotent stem cell derived mural cell phenotypes. Frontiers in Bioengineering and Biotechnology, 8, 278. https://doi.org/10.3389/fbioe.2020.00278.

59. Kim, J., Koo, B.-K., \& Knoblich, J. A. (2020). Human organoids: Model systems for human biology and medicine. Nature Reviews. Molecular Cell Biology, 21(10), 571-584. https://doi.org/10.1038/ s41580-020-0259-3.

Publisher's Note Springer Nature remains neutral with regard to jurisdictional claims in published maps and institutional affiliations. 